\title{
The Role of Universities in Shaping the Evolution of Silicon Valley's Ecosystem of Innovation
}

\author{
Josep M. Piqué \\ La Salle - Ramon Llull University Innova Institute \& Technova Barcelona \\ Sant Joan de La Salle, Barcelona, Spain \\ jmpique@salleURL.edu \\ Jasmina Berbegal-Mirabent* \\ Department of Economy and Business Organization, Universitat \\ Internacional de Catalunya, Barcelona, Spain \\ jberbegal@uic.es \\ Henry Etzkowitz \\ International Triple Helix Institute (ITHI), Palo Alto, USA \\ henry.etzkowitz@triplehelix.net
}

\begin{abstract}
Universities play a unique role in ecosystems of innovation. They interact with the other agents of the Triple Helix model, developing their functions in relation to each other and together with industry and government. Grounded in key conceptual frameworks-Triple Helix, Regional Innovation Systems and Entrepreneurial University - we analyze how the leading universities in Silicon Valley (UC Berkeley, Stanford and UC San Francisco) have evolved, adapting to new demands and, in turn, shaping the evolution of Silicon Valley. To do so we use quantitative and qualitative data and examine the changes occurring between 2007 and 2018. A close examination of the data from this period reveals an increased attention to entrepreneurship education and an intensified activity of technology transfer offices. Equally relevant are the increased interactions between universities and investors (business angels, Venture
\end{abstract}

* Corresponding author: Department of Economy and Business Organization, Universitat Internacional de Catalunya, C. Immaculada, 22. o8017 Barcelona, Spain. 
Capital funds and corporate investors), and the improvement of specific infrastructures to incubate and accelerate business ideas.

\title{
Keywords
}

Ecosystems of innovation - Entrepreneurial universities - Evolution - Silicon Valley Triple Helix

\section{Arabic}

\author{
دور الجامعات في تطوير نظام إبداع وادي السليكون \\ Josep Miquel Pique \\ Jasmina Berbegal-Mirabent \\ Henry Etzkowitz
}

املخص

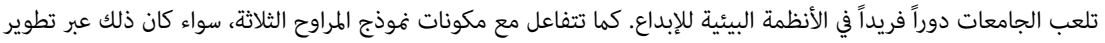
وظائفهم البينية أو المرتبطة بالمجال الصناعي والإدارة.استنادا على الأطر المفاهيمية الرئيسية - المراوح الثلاثة، نظم الابتكار الإقليمية

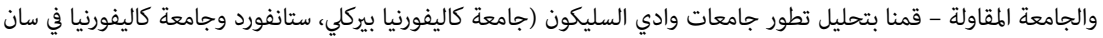

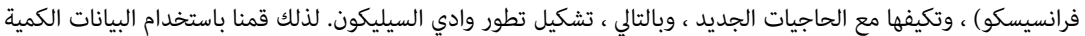

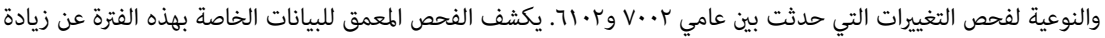

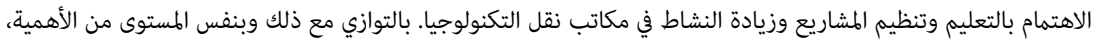

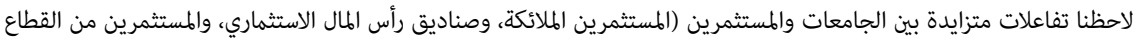
الخاص) وتحسين البنية الأساسية الخاصة باحتضان وتشجيع الأفكار في مجال الأعمال.

الكلمات المفتاح

الأنظمة البيئية للإبداع، الجامعات المقاولة ،وادي السليكون، التطور،المراوح الثلاثة 


\title{
Chinese
}

\section{大学在促进硅谷创新生态系统进化中的作用}

\author{
Josep Miquel Pique \\ Jasmina Berbegal-Mirabent \\ Henry Etzkowitz
}

\section{摘要}

大学在创新生态系统中扮演着独特的角色。他们与三螺旋模型的其它主体 进行互动, 在与产业和政府彼此矢联中发展它们的功能。基于主要的概念 框架——三螺旋、区域创新系统和创业型大学, 我们分析了硅谷的领先大 学(斯坦福大学、加州大学伯克利分校和旧金山分校)如何发展, 适应新需 求, 进而促进硅谷的进化。为此, 我们利用定量和定性数据分析, 研究 2007 年至 2016 年之间发生的变化。仔细检查这一时期的数据, 可以发现人们 对创业教育的矢注度越来越高, 技术转让办剬室的活动也越来越多。同样 重要的是, 大学与投资者(商业天使, 风险投资基金和企业投资人)之间不断 增强的互动, 以及用于孵化和加速商业理念的特定基础设施的改善。

\section{关键词}

创新生态系统, 创业型大学, 硅谷进化, 三螺旋 


\title{
French
}

\section{Le rôle des universités dans le façonnage de l'évolution de l'écosystème d'innovation de la Silicon Valley}

\author{
Josep Miquel Pique \\ Jasmina Berbegal-Mirabent \\ Henry Etzkowitz
}

\section{Résumé}

Les universités jouent un rôle unique dans les écosystèmes d'innovation. Elles interagissent avec les autres agents du modèle de la Triple Hélice, développant leurs fonctions en relation avec chacun d'entre eux individuellement et avec l'ensemble constitué de l'industrie et du gouvernement. Nous basant sur des cadres conceptuels clés - Triple Hélice, Systèmes d'innovation régionaux et université entrepreneuriale nous analysons comment les principales universités de la Silicon Valley (UC Berkeley, Stanford et UC San Francisco) ont évolué, s'adaptant aux nouvelles demandes et, à leur tour, façonnant l'évolution de la Silicon Valley. Pour ce faire, nous utilisons des données quantitatives et qualitatives et examinons les changements survenus entre 2007 et 2016. Un examen attentif des données de cette période révèle une attention accrue à la formation à l'entrepreneuriat et une activité intensifiée des bureaux de transfert de technologie. Sont également apparues pertinentes, les interactions accrues entre les universités et les investisseurs (business angels, fonds de capital-risque et investisseurs corporatifs), et l'amélioration d'infrastructures spécifiques pour incuber et accélérer les idées d'entreprise.

\section{Mots-clés}

écosystèmes d'innovation - universités entrepreneuriales - Silicon Valley - évolution triple hélice 


\title{
Portuguese
}

\section{O papel das universidades na formação da evolução do ecossistema de inovação da Silicon Valley}

\author{
Josep Miquel Pique \\ Jasmina Berbegal-Mirabent \\ Henry Etzkowitz
}

\section{Resumo}

As universidades desempenham um papel único nos ecossistemas de inovação. Eles interagem com os outros agentes do modelo Triple Helix, desenvolvendo suas funções em relação um ao outro e em conjunto com a indústria e o governo. Fundamentado nos principais conceitos estruturas - Triple Helix, Sistemas Regionais de Inovação e Empreendedorismo University - analisamos como as principais universidades da Silicon Valley (UC Berkeley, Stanford e UC San Francisco) evoluíram, adaptando-se a novas demandas e, por sua vez, moldando a evolução da Silicon Valley. Para isso, usamos quantitativa e qualitativa dados e examinar as mudanças ocorridas entre 2007 e 2016.

O exame dos dados desse período revela uma atenção crescente ao educação para o empreendedorismo e uma atividade intensificada dos escritórios de transferência de tecnologia. Igualmente relevante é o aumento das interações entre universidades e investidores (business angels, fundos de capital de risco e investidores corporativos) e os melhoria de infra-estruturas específicas para incubar e acelerar ideias de negócio.

\section{Palavras chave}

ecossistemas de inovação - universidades empreendedoras - Silicon Valley evolução - hélice tripla 


\title{
Russian
}

\section{Роль университетов в формировании эволюции экосистемы инноваций Силиконовой долины}

\author{
Хосеп Микель Пике \\ Жасмина Бербегал-Мирабент \\ Генри Эикович
}

\begin{abstract}
Аннотация
Университеты играют уникальную роль в инновационных экосистемах. Они взаимодействуют с другими агентами модели Тройной спирали, развивая свои функции по отношению друг к другу и вместе с промышленностью и правительством. Основано на ключевых концептуальных рамки - Тройная спираль, региональные инновационные системы и предпринимательство Университет - мы анализируем, как ведущие университеты в Силиконовой долине (Калифорнийский университет в Беркли,Stanford и UC San Francisco), адаптируясь к новым требованиям и, в свою очередь,формирование эволюции Силиконовой долины. Для этого мы используем количественные и качественные данные и изучить изменения, произошедшие между 2007 и 2016 годами.

Изучение данных за этотпериодпоказываетповышенное вниманиекобучение предпринимательству и активизация деятельности бюро по передаче технологий.Не менее актуальным является расширение взаимодействия между университетами и инвесторами(бизнес-ангелы, венчурные фонды и корпоративные инвесторы), а также

совершенствование конкретной инфраструктуры для инкубации и ускорения бизнес-идей.
\end{abstract}

\section{Ключевые слова}

инновационные экосистемы - предпринимательские университеты Силиконовая Долина - эволюция - тройная спираль 


\title{
Spanish
}

\section{El papel de las universidades en la configuración de la evolución del ecosistema de innovación de Silicon Valley}

\author{
Josep Miquel Piqué \\ Jasmina Berbegal-Mirabent \\ Henry Etzkowitz
}

\section{Resumen}

Las universidades desempeñan un papel único en los ecosistemas de innovación. Interactúan con los otros agentes del modelo de la Triple Helix; desarrollando sus funciones en relación entre sí y junto con la industria y el gobierno. Tomando como punto de partida los marcos teóricos de la triple hélice, los sistemas regionales de innovación el de la universidad emprendedora; en este estudio se analiza cómo las universidades líderes de Silicon Valley (UC Berkeley, Stanford y UC San Francisco) han evolucionado, adaptándose a las nuevas demandas y, a su vez, contribuyendo a la evolución de Silicon Valley. Para ello se combina el uso de datos cualitativos y cuantitativos para investigar los cambios ocurridos entre 2007 y 2016.

Del análisis de los datos de este período se desprende un creciente énfasis en la educación emprendedora y un incremento de la actividad desarrollada por las oficinas de transferencia de tecnología.

Igualmente relevantes son las mayores interacciones que se han observan entre universidades e inversores (business angels, fondos de Venture Capital e inversores corporativos), y la mejora de infraestructuras específicas para incubar y acelerar ideas de negocio.

\section{Palabras clave}

ecosistemas de innovación - universidades emprendedoras - Silicon Valley evolución - triple hélice 
Silicon Valley is the archetype of ecosystems of innovation (Pique et al. 2018; Engel 2015; Saxenian 1996). Its growth, organic and policy directed, is a mix of bottom up and top down initiatives that scaled thanks to a rich compost of government and private investments to support science, technology, firm formation and growth (Engel 2014). Indeed, the northern California venture capital industry emerged as a public-private collaboration, encouraged by the Small Business Act of 1959 while donors from the fortunes created in the Valley feedback resources into academic development. UC Berkeley and Stanford were key sources of Silicon Valley, serving as a magnet, attracting talent, technology and capital to an effervescent ecosystem that is constantly generating new ideas which very quickly take the form of a new venture (Gold 2018). The role of universities in attracting talent to the region has been addressed by Saxenian (2006) and Scott and Kirst (2017), who point to shortfalls in the region's academic capacities beyond the three academic institutions focused upon in this analysis that drives the importation of global talent.

The diversification of industries and sectors - rather than specializing in a few-fueled that technology rapidly spread across sectors (St. Clair 1998). These interactions were stimulated during the second half of the 19th century thanks to the creation of two universities: University of California, Berkeley (UC Berkeley) (1868) and Stanford University in Palo Alto (1891). Berkeley took the lead in creating joint projects with government even as Stanford took the lead with industry. These two strands eventually converged with both universities actively engaging with the public and private sectors. Very soon, these universities went a step further and started formalizing the collaboration between government and industry. The development and/or commercialization of telephone, electronics, nuclear and computer technologies played a key role at this stage (Angel 1991).

A critical mass of like-minded academic entrepreneurs was created, hastening the establishment of new ventures: public, private and academic, including national laboratories, start-up firms and interdisciplinary research centers. A variety of novel formats were invented or expanded upon, including venture capital and the university research park. The latter was a by-product of a "failed" effort to develop an ordinary industrial park, capitalizing some of Stanford's abundant land resources to help support the university. The firms that were attracted, however, were ones that had grown out of the research at the university, like Hewlett-Packard or sub-units of large firms that wished to access academic resources, giving rise to the science park concept (Etzkowitz and Zhou 2018a). Large corporations (e.g. Lockheed Martin, Xerox and Iвм) 
were also attracted to the region and opened their R\&D centers there. In the 1970s, the number of firms developing in the area increased considerably. This growth was possible thanks to the parallel expansion of the venture capital (VC) industry (Kenney and Florida 2000).

In 1980 the Bayh-Dole Act changed the landscape of research commercialization, encouraging a broader range of academic institutions to capitalize their knowledge. Universities - and also small businesses and non-profit organizations - were now able to elect to retain the ownership to inventions made under federal funding (i.e. research programs). The enactment of this law instigated universities taking the lead in patenting and licensing discoveries (Mowery et al. 2001) as well as a new movement of VC investments. Japanese competition in the 1980s, led to the development of new models of university-industry-government cooperation, such as the industry led effort with government support during the Reagan era, creating the Stanford Center for Integrated Systems that regained US leadership in the chip industry, "the silicon" in Silicon Valley. A Triple Helix brainstorming initiative, Joint Venture Silicon Valley responded to the early 199os recession with a focus on networking technologies.

Subsequent waves of innovation include the dot-com bubble in the 199os and more recently, the focus has moved towards social media, clean-tech energy and AI. Today the valley is home to some of the world's largest corporations and thousands of startup companies in these new industries. As in many other innovation enclaves, new demands have arisen in Silicon Valley and the different agents in the ecosystem have been called to reconstruct their roles to rapidly adapt to these new challenges (Pique et al. 2018). Thus, it is of principal interest to identify and map out the impact of the different interventions that stimulated the evolution (Engel 2015). Literature examining how universities are effective catalysts for leadership, infrastructure and provide innovation development cohesion in an ecosystem of innovation is available (Cai and Liu 2014; Liu and Cai 2017). Yet, relatively little is known about how universities re-adjust their role over time, and the consequences of their actions on the ecosystem (Pique et al. 2018).

Building upon three main conceptual frameworks, namely the Triple Helix model, the theory of Regional Innovation Systems (RIS) and the Entrepreneurial University, we shed new light on the evolution of the role played by universities in relation with industry and government. Our empirical setting is Silicon Valley, one of the top ecosystems of innovation that include complex interrelations among entrepreneurs, researchers, venture capitalists, service providers, lawyers, accountants and marketing professionals that are constantly shape-shifting in order to stay ahead of technological changes and consumer 
trends (Etzkowitz 2019; Henton and Held 2013). Like in other ecosystems of innovation, universities are key agents, acting as lighthouse institutions and with multiple ways to achieve their influence. More specifically, in this study we address the following research questions: How have universities in Silicon Valley developed responses to the changes that have occurred in this entrepreneurial ecosystem over the years? What are the drivers for these responses?

To answer to these questions, we analyze those actions and strategies undertaken by universities interacting with industry and government, following the Triple Helix model. Particularly we focus our attention on those initiatives aimed at boosting entrepreneurship, a key element to secure the growth and dynamism of an innovation ecosystem. A 12-years horizon is considered, covering the years 2007 to 2018 . Combining quantitative and qualitative data we conclude that universities are active in four main domains, all oriented towards accelerating new company development: entrepreneurial education, sources of knowledge, investment activities and facilities.

The rest of the article is structured as follows. First, in Section 2 we review the literature on innovation ecosystems and the role played by universities. Section 3 describes the method followed to gather data and present the information. Next, in Section 4 we dive deeper into the universities in Silicon Valley that are analyzed. The strategies followed by universities to nurture the innovation ecosystem are discussed in Section 5 . The paper ends with the concluding remarks in Section 6 addressing the unintended consequences of an unbalanced Triple Helix.

Innovation Ecosystems and the Role played by Universities

Recent studies on regional development processes emphasize the importance of knowledge flows, innovative processes and networking strategies among the different actors of an ecosystem of innovation (Oh et al. 2016; Carayannis and Campbell 2009). According to Cooke et al. (2003), if interactions are adequately managed, the convergence of all these agents can help regions revitalize their industry and develop economically, maximizing the economic benefits. Universities have a significant impact on regional development, in both the short and the long term (Cai and Liu 2014). Specifically, the university has been transformed from a secondary to a primary agent for economic development (Etzkowitz and Zhou 2018b).

In a knowledge-driven society, science has become central to the generation of welfare (Harris 2011), not surprisingly, outcomes emerging from research are needed in a number of social and economic activities. Increasingly, 
companies—either large or small—are highly dependent upon knowledge systems. As pointed out by Carlaw et al. (2006), knowledge itself has become a commodity, to the extent that the production of knowledge is not limited to its discovery but it also involves its application (Nilsson 2005), blurring the different steps and involving a broader community of people.

The relevance of knowledge and, by extension that of institutions involved in its generation, is undeniable (Morgan 2004). Said differently, universitiesand other knowledge-creator institutions - play a key role as resource endowments within the region for its own development. They do not only stimulate wealth creation and support sustainable development, but they do so by becoming active contributors in fostering regional prosperity and competitive advantage (Orecchini et al. 2012, Brundenius et al. 2016). To respond to this call, universities have shifted their agendas, moving from the desire to increase the general education level of the population and the scientific output (Hazelkorn 2005) towards the adoption of the commitment to improve the regional development of its community (Goddard et al. 2016). In other words, the "third role" must be fully combined with the two other traditional missions: teaching and research.

To regionally engage implies responding to a wide variety of needs, going beyond economic and technical advances. This translates into saying that universities should encourage the development of high value-added activities, which in turn, promote the capitalization of capital and talent (Shattock 2009). Notwithstanding, it is worth mentioning that this is occurring in an era of global competition (Charles 2006), therefore, it is not only about being committed locally, but also in attracting involvement of researchers, students and other stakeholders (i.e. industry partners). Literature on the regional engagement of universities reveals that better performance rates can be reached through trilateral interactions. In order to conceptualize the evolution of the role of universities in innovation systems and the driving forces of these changes, similar to previous studies (Liu and Cai 2017), we use the Triple Helix model of university, industry, and government relations.

Triple Helix takes into account that the boundaries between universities and industries, science and technology, and private and public institutions are fading, giving birth to a system of multiple connections that overlap in different dimensions (Etzkowitz 1993; Leydesdorff and Etzkowitz 1996; Etzkowitz and Zhou 2018a). Compared to previous developments in which universities were conceived as supportive mechanisms, under this approach, universities are acknowledged to play a leading role in innovation alongside government and industry. Each helix of the model — university, industry and governmenthas an internal core and an external field space, both movements being 
produced simultaneously. On the one hand, there is the vertical dimension, in which each helix develops according to its own specific strategy. The internal changes and movements that each helix experience, occur irrespectively of the actions of the other helixes. On the other hand, there is a horizontal dimension, where all helixes interact with the others. The natural consequence of these movements is an innovative and creative environment, where knowledge flows in all directions, mirroring the complexity of the interactions and relationships that occur at different stages of the process of knowledge capitalization (Etzkowitz and Zhou 2018b).

For the purpose of this study we rely on this theoretical framework and examine initiatives involving the university that aim at better connecting it with the other two helixes: the industry and the government. Yet, the applicability of this model has been contested (Uyarra 2010), for obscuring the dynamic micro-foundations of university-industry-government interactions (Tuunainen 2005). Universities are embedded in a particular geographical context, and therefore, their analysis should be performed in a way that the specificities of the location are taken into account. Accordingly, we use the Triple Helix model to connect the traditional categories of the innovation economy with institutional and evolutionary economics, and the theory on Regional Innovation Systems, which provides the institutional infrastructure supporting innovation within the production structure of a region (Asheim and Coenen 2005).

Identified by Etzkowitz (1983) and later developed by Clark (1998), the concept of "entrepreneurial university" emerged as a key element of the Triple Helix. we see in the universities under analysis that their role is broader than only generating and transferring knowledge. As stated in (Nelles and Vorley 2010, Guerrero et al. 2015) entrepreneurial universities contribute and provide leadership for the creation of entrepreneurial thinking, actions and institutions. First, they are relevant sources of new talent and cutting-edge technology (Pique et al. 2019). Second, in the urban dimension, they develop land and buildings as anchor institutions. Third, in the economic dimension, they provide science, technology, labs and entrepreneurs to the ecosystem. Finally, in the social dimension, they provide fresh talent and experienced staff that might be willing to live in the area of innovation.

\section{$3 \quad$ Methodology}

\subsection{Sample}

As previously explained, the valley was created around two universities: UC Berkeley and Stanford which, together with USCF, are the focus of our study. 
These universities have had — and are still having — a significant impact on the other agents in the ecosystem. For instance, many of the founders of startups in Silicon Valley have studied there, receiving a highly entrepreneurial education. Likewise, companies are in direct contact with these universities, getting experienced advice - in the early stages-and from other companies related to the universities - mainly in the launching and later stages of business development - at a low transaction-cost basis.

According to CBInsights (2012), in 2012 companies created by Stanford alumni raised $\$ 4.1$ billion across 203 financings, leaving far behind the other universities in terms of deal activity. On funding raised, Stanford also had a high performance, only exceeded by UC Berkeley, keeping alumni in their home state $-85 \%$ of Stanford alumni and $88 \%$ of UC Berkeley chose to set up their companies in California.

Although Silicon Valley has always been somewhat geographically dispersed, recent moves from Palo Alto to San Francisco and San José by leading firms seem to signal that its center of gravity might be shifting to multiple nodes (Engel and Forster 2014, Florida 2012). San Francisco is unique in its atmosphere, with both a lively and energetic street culture, bohemian, gay and high cultures. Numerous networking events run by consulting and other organizations encourage serendipitous exchanges, which in turn, are likely to yield in convenient networks and durable bonds for the development of innovative endeavors, overriding the tendency of high-tech firms to keep their personnel in-house with offers of free food and other perks. The city is filled with trendy districts where high-income millennials and young techies want to live and work but gentrification is making the city increasingly unaffordable to others (Engel et al. 2018). Digging deeper into the analysis of startup ecosystems in cities, San Francisco is listed first (among 954 cities across 125 countries around the world) in the Startup Ecosystem Ranking (2019) elaborated by StartupBlink. ${ }^{1}$ On a related note, the Global Index of Innovation ${ }^{2}$ (2019), in its special section presenting the world's largest science and technology clusters, puts together the region of San Francisco-Oakland-Fremont with the area of San Jose, being listed as the fifth leading region in the world. Taken all together it is not surprising that San Francisco has become a recruiting tool by itself and is nowadays considered as part of Silicon Valley. Accordingly, we also include a third university in our study: University of California San Francisco (UCSF), a key player in the emergence of the region's biotechnology industry.

\subsection{Data Collection and Analysis}

For the purpose of this research we collected information about the evolution of the role of the universities in Silicon Valley. Several sources were used: (1) webpages of the universities, reports, leaflets and press releases, (2) site visits, 
and (3) scholarly publications describing the evolution of Silicon Valley. From all these documents we selected and reviewed those dealing with the initiatives, programs and incentives aimed at fostering entrepreneurship that were approved, started or finished during the period under analysis (2007-2018) in UC Berkeley, UCSF and Stanford University. Information concerning performance in technology commercialization was also collected from the offices of technology licensing. Unfortunately, not all universities reported data in the same way. We were, however able to collect homogenous information on key performance indicators referring to four main dimensions, all of the them, related to outputs that entrepreneurial universities are expected to produce (Rothaermel et al. 2007):

- Expenditure: research expenditures

- Invention disclosures: inventions disclosed, total active inventions

- Patent protection and licenses: US patents issues, utility licenses issued

- Licensing and royalties from new products/startups: inventions earning royalties/fees, income from royalties and fees, inventor shares

Ten semi-structured interviews with key informants were also conducted. Specifically, we wanted to include in our panel experts from different areas, gathering different perspectives about how universities have evolved. Accordingly, we interviewed people from the industry (business angels, corporate investor, corporations, and entrepreneurs), university professors (with sound expertise in the field of ecosystems of innovation) and representatives from public administrations (local and state levels). Note that the interviews covered the three agents in the Triple Helix model as movements in one of the agents might originate movements in the others. Put differently, to understand how universities evolved it is imperative to investigate how they perceived the impact of these movements on their functions and on the entire ecosystem. These interviews were conducted between March and July 2017 and lasted between 45 and 90 minutes for each of the informants. All interviews were recorded, transcribed and cross-checked with the original recordings to ensure accuracy. The content was then coded and thematically analyzed. An assistant researcher and two additional researchers further assisted in the process. Table 1 shows the experts interviewed.

Furthermore, several discussions with entrepreneurs and innovation managers from Silicon Valley were held during the 2017 Stanford STS 186 Seminar on Triple Helix Innovation and Entrepreneurship including, for instance, the director of the Stanford Research Park (Etzkowitz et al. 2019; Etzkowitz et al. 2018). The purpose of these interviews was to determine the underlying reasoning for shifts in strategy. Following the standards in qualitative studies (Merton et al. 1990), data collection was considered to be complete when 
TABLE 1 Experts interviewed

\begin{tabular}{lll}
\hline Agent & Role & Organization \\
\hline Industry & $\begin{array}{l}\text { Business angel network } \\
\text { Business angel }\end{array}$ & $\begin{array}{l}\text { Keiretsu Forum } \\
\text { SandHill Angels, Silicon } \\
\text { Catalyst }\end{array}$ \\
& Corporate investor & Samsung Catalyst Fund \\
& Corporate & IDEO, Dropbox, NIO \\
& Entrepreneur & Sensing Systems \\
& Entrepreneur & Promptu \\
& University professor & University of California \\
& & System \\
University & Sniversity professor & Stanford University \\
& Local government & San José City Council \\
Public administration & Citate government & \\
& &
\end{tabular}

(i) successive investigations provided no additional relevant information; (ii) information was triangulated by at least two different sources of information; and (iii) data gathered from different sources were consistent, and offered a unique view of the phenomenon under study.

Section 4 summarizes the main findings from this analysis. The information presented comes from following a rigorous method. We first looked at the annual reports of the three universities and selected those initiatives/activities that were purposefully highlighted by the universities. Their relevance was later discussed during the interviews with the experts. Finally, we also confronted this information with reports and articles authored by independent organizations or researchers with a different affiliation from Stanford or UCв/UCSF (to avoid potential biases). Although this information is not homogenous across universities, we report information in a similar way. Next, in Section 5 we elaborate on the strategies followed by universities to "feed" the innovation ecosystem.

\section{A Closer Look at the Universities located in Silicon Valley}

Universities in Silicon Valley have expanded the ways that they support their entrepreneurs and researchers. In this section we provide a general overview of their main achievements in terms of technology transfer activities. Also, we 
report relevant policies or initiatives (e.g. innovation hubs, technology centers, support offices and funds) that these universities implemented to boost entrepreneurship and better respond to the market demands. In order to provide more comparable results, Table 3 displays a set of indicators from which data were available for the period of interest and displayed in the same way for the three universities.

\subsection{University of California System}

The University of California (UC) has ten campuses around California: UC Davis, UC Berkeley, UC San Francisco, UC Santa Cruz, UC Merced, UC Santa Barbara, UC Riverside, UC Los Angeles, UC Irvine and UC San Diego. As a whole, the university has been granted more patents than any other university in the world and has over 30 accelerators and incubators. Counting only startups in STEM-related fields 1,267 companies were created between 1968 and June 2015 . But this growth is more relevant during the last years: $75.4 \%$ of these UCaffiliated companies were established between 2000 and 2015 , and only in 2015 , UC research gave rise to 85 new startups and 1,756 new inventions - which implies about five inventions disclosed daily. Table 2 shows the main indicators in terms of technology commercialization for the period under study.

Four UC system units facilitate innovation, entrepreneurship and technology commercialization:

- Innovation Alliances and Services (IAS): launched in 1978 as the UC Office of Technology Transfer to run the licensing activities for all UC campuses. Since 1990 - when UC began decentralizing technology transfer operationsthe IAS has expanded its functions, supporting campuses building partnerships and collaborations with the industry.

- UC Investments (Office of the Chief Investment Officer of the Regents): manages the participation in shares coming from licensing transactions and through incubators.

TABLE 2 Performance of the UC system. Period 2007-2018

\begin{tabular}{llllll}
\hline Year & $\begin{array}{l}\text { US } \\
\text { patents } \\
\text { issued }\end{array}$ & $\begin{array}{l}\text { New } \\
\text { technology } \\
\text { disclosures }\end{array}$ & $\begin{array}{l}\text { Utility } \\
\text { licenses } \\
\text { issued }\end{array}$ & $\begin{array}{l}\text { Startup } \\
\text { companies } \\
\text { formed }\end{array}$ & $\begin{array}{l}\text { Patent royalty \& fee } \\
\text { income (new products } \\
\text { and startups) }\end{array}$ \\
\hline 2007 & 243 & 1,629 & 167 & 52 & $\$ 149.01 \mathrm{M}$ \\
2018 & 615 & 1,735 & 233 & 94 & $\$ 200.61 \mathrm{M}$ \\
\hline
\end{tabular}

SOURCE: UC TECHNOLOGY COMMERCIALIZATION REPORT (2019) 2007 \& 2018, ADAPTED 
- Research Policy Analysis and Coordination (RPAC): develops and implements policy concerning all funded research at UC system. It also includes policies related to patents, equity, and industry.

- Office of the General Counsel: provides legal oversight of intellectual property and technology commercialization activities.

With the aim of promoting a stronger environment for entrepreneurs and startup investors, several changes occurred within the UC system. In November 2013 the Innovation and Entrepreneurship Initiative, led by UC's President Janet Napolitano, was launched, together with on-going campus efforts, spurring entrepreneurial activity across the UC system. For instance, in 2014 the Innovation Council was created, composed of investors, tech leaders and industry experts from outside the UC system, as an advisory board to the UC Office of the President on issues dealing with innovation, entrepreneurship and the commercialization of technology. Another initiative was the Research Catalyst Awards, created in 2014, a \$10 million multi-campus fund to conduct research with impact on society. Cross-campus collaboration is also enhanced, with research applications that must include at least three UC different campuses. Similarly, in 2015, primeUC was launched, a competition for early-stage startups coming from the UC system. The first competition was organized by $Q_{3} 3$ in San Francisco with a prize for seed funding of $\$ 300$,ooo provided by an industrial partner.

In December 2015, the creation of a \$250 million fund from the university's endowment to invest in startups coming out of the UC system was announced, with a primary focus on catalyzing startups in key sectors such as energy or agriculture. UC Investments also invested another \$25 million in other local venture capital funds. In early 2016, some changes were announced, allowing UC to invest in infrastructure on all its campuses to better support prospective startup entrepreneurs.

\subsection{UC Berkeley}

UC Berkeley, with over 25,000 undergraduate and 10,000 graduate students, launched. various initiatives in recent years. Appendix A lists some of the most relevant ones. It is worth highlighting that many of them are student or alumni-led activities, resulting in creation of a stronger ecosystem for entrepreneurs in UC Berkeley.

UC Berkeley's accomplishments include over 1,568 active inventions and 739 active US patents (data from 2018). Since 2005, over 187 startups have been founded to commercialize inventions and copyrights under licenses from IPIRA (Intellectual Property \& Industry Research Alliances), attracting \$1.6B from VC investors and $\$ 51 \mathrm{M}$ in SBIR/STTR grants. 29 Startups exits have produced 


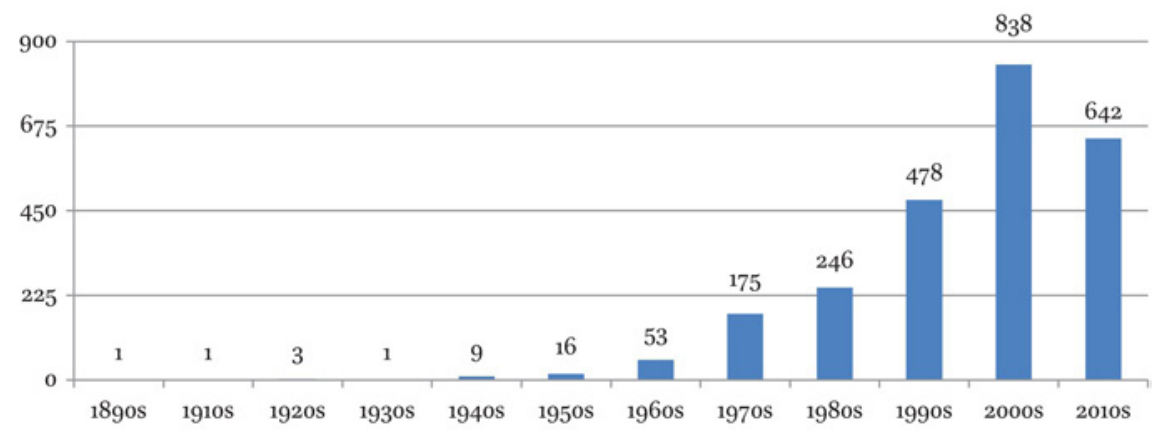

FIGURE 1 Number of firms with Berkeley founders, by founding decade SOURCE: UC BERKELEY: STIMULATING ENTREPRENEURSHIP IN THE BAY AREA AND NATIONWIDE, BY BAY AREA ECONOMIC COUNCIL INSTITUTE

$\$ 8.1 \mathrm{~B}$ in cash and stock options. 66 Berkeley startups currently employ 1,543 persons, generating $\$ 195 \mathrm{M}$ in annual revenue in the Bay Area (2014).

Based on the conclusions of a 2012 study made by UC Berkeley (2014), 3,744 founders and 2,610 companies were identified among alumni, faculty, and affiliates. With significant variations by industry, the above firms account for 542,433 jobs, and employ, 208 workers each, on average. The number of firms with UC Berkeley founders is shown in Figure 1.

\subsection{UC San Francisco}

UC San Francisco (UCSF) mainly focuses on life sciences and medicine at graduate-level. Similar to UC Berkeley, in the recent years several initiatives have aimed at consolidating the entrepreneurial ecosystem and fostering startup creation (see Appendix B for a detailed list of the main initiatives). A report developed by the Bay Area Council Economic Institute shows that UCSF originated more than 185 life sciences enterprises during the $1968-2015$ period. Of these, 98 remain active, with $83 \%$ of them belonging to the life sciences.

UCSF "pencilled in" an incubator space into its new Mission Bay campus, founded in 1999. A financially independent investment firm, operating under the university's auspices, created a series of purpose-built incubators $\left(\mathrm{QB}_{3}\right)$ within and around the campus, attracting spin-offs from UCSF and elsewhere in the region, including Stanford that lacks a similar facility. Indeed, some 80 biotech companies and incubators have moved into the neighbourhood in the 15 years since UCSF Mission Bay broke ground in 1999. R\&D units of big pharma companies have also been attracted to Mission Bay, and some, like J\&J early awareness unit Janssen Labs located in QB3.

Table 3 summarizes the most relevant indicators in technology commercialization, and confronts them with those from UC Berkeley and Stanford University. 
TABLE 3 Performance of UC Berkeley, UCSF and Stanford. Period 2007-2018

\begin{tabular}{|c|c|c|c|c|c|c|}
\hline & \multicolumn{2}{|c|}{ UC Berkeley } & \multicolumn{2}{|c|}{ UC San Francisco } & \multicolumn{2}{|l|}{ Stanford } \\
\hline & 2007 & 2018 & 2007 & 2018 & 2007 & 2018 \\
\hline $\begin{array}{l}\text { NSF Research } \\
\text { expenditures }\end{array}$ & $\$ 591.7 \mathrm{M}$ & $\$ 796.5 \mathrm{M}$ & $\$ 885.1 \mathrm{M}$ & $\$ 1,595 \cdot 7 \mathrm{M}$ & $\$ 702 \mathrm{M}$ & $\$ 1,157 \mathrm{M}$ \\
\hline Inventions disclosed & 155 & 201 & 200 & 232 & $35^{\circ}$ & 560 \\
\hline $\begin{array}{l}\text { Inventions earning } \\
\text { royalties/fees }\end{array}$ & 187 & 217 & 315 & 385 & 546 & 813 \\
\hline Total active inventions & 1,017 & 1,568 & 1,422 & 1,988 & 2,814 & NA \\
\hline US patents issues & 36 & 95 & 35 & 60 & $15^{\circ}$ & 226 \\
\hline Utility licenses issued & 20 & 24 & 44 & 42 & 107 & $15^{\circ}$ \\
\hline $\begin{array}{l}\text { Income from royalties } \\
\text { and fees }\end{array}$ & $\$ 5.20 \mathrm{M}$ & $\$ 14.66 \mathrm{M}$ & $\$ 62.4 \mathrm{OM}$ & $\$ 38.16 \mathrm{M}$ & $\$ 61.3 \mathrm{oM}$ & $\$ 40.96 \mathrm{M}$ \\
\hline Inventor shares & $\$ 1.54 \mathrm{M}$ & $\$ 1.44 \mathrm{M}$ & $\$ 23.5 \mathrm{oM}$ & $\$ 6.19 M$ & $\$ 16.9 \circ \mathrm{M}$ & $\$ 9.55 \mathrm{M}$ \\
\hline
\end{tabular}

SOURCE: UC TECHNOLOGY COMMERCIALIZATION REPORT (2019) 2007 AND 2018, AND OTL STANFORD UNIVERSITY ANNUAL REPORTS (2007-2016) 2007 AND 2016, ADAPTED. NA: NOT AVAILABLE

Some of the above businesses have generated spin-offs, creating new descendants of UCSF startups. However, a complete investigation of the number of companies that have emerged in UCSF ecosystem is complex. The rationale lies in the difficulty in tracing all companies that may have connection with UCSF. Moreover, since UCSF focuses on life sciences, companies originated by the UCSF research or spin-offs may create other startups. To measure the impact of UCSF, one can grant some credit to the increase in number of biotech firms and jobs in the Bay Area (see Table 4) to all the activities promoted by UCSF in this field.

TABLE 4 Evolution of biotech firms in Silicon Valley

\begin{tabular}{lrrr}
\hline & $\mathbf{2 0 1 0}$ & $\mathbf{2 0 1 5}$ & Increment \\
\hline Biotech jobs & 333 & 1,448 & $3334.83 \%$ \\
Biotech firms & 23 & 89 & $286.96 \%$ \\
Average salary & 9,477 & 13,464 & $42.07 \%$ \\
\hline
\end{tabular}

SOURCE: UCSF IMPACT REPORT (2016), ADAPTED 


\subsection{Stanford University}

Stanford University has a rich record on innovation and entrepreneurship, with a broad array of organizations, programs, initiatives and funds available to students, researchers, alumni and the academic community. Appendix $\mathrm{C}$ lists the initiatives - either inside or outside the campus - that are expected to help Stanford entrepreneurs to create new ventures or help them to expand their links and receive advice about their entrepreneurial endeavors.

The impact of Stanford on Silicon Valley's ecosystem is usually linked to the success of corporations such as Cisco, Silicon Graphics or Sun Microsystems in the early 1980s, and Google, Yahoo or VMware in the 199os. All of them were created by Stanford community members or based on Stanford research. Yet, in the big picture scheme of Silicon Valley, the Stanford's Office of Technology Licensing (OTL) is involved in a relatively small portion ( $5 \%$ of the startups), taking part only in those cases where the firms' Stanford connection incorporates IP that is licensed from the university. From its 1970 founding until quite recently, OTL emphasized the distribution of its output to the best qualified party, a criterion that might seem to put a start-up at a disadvantage in comparison to resources of an existing firm. On the other hand, oTL has always been sensitive to the wishes of influential faculty and has in the end, after exercise of due diligence, usually licensed to inventors when they wished (Etzkowitz 2013).

Startup licenses are a small part of the licenses signed annually by the отL. In the past, only around $10 \%$ of new licenses per year gave birth to a new company. Notwithstanding, in the last few years, отL doubled the number of licenses to startups per year, and granted more options to license to entrepreneurs. In 2013, the Stanford Innovation Program (sip) began as an experiment to use university funding to mature unlicensed inventions to transform them into more licensable ones. Compared to 2007, twelve years later the number of new technologies disclosed raised from 400 to 560 , and the number of license agreements significantly increased (from 107 to 150). Likewise, the number of startups in which Stanford held equity as a result of license agreements almost doubled (from 14 to 24). Yet, revenues from gross royalties decreased from $\$ 62.5 \mathrm{M}$ from 546 technologies to $\$ 40.96 \mathrm{M}$ coming from 813 technologies. Ecosystem

As new firms have created the majority of the net job growth over the last 20 years in the US, it is increasingly recognized that universities are a place for 
connections, where entrepreneurs may access talent and technology. In the past, universities did not capitalize those assets, thus, not taking advantage of the opportunity to create new companies from tech entrepreneurs of their classrooms and labs. In order to capture the best entrepreneurs to be, universities involve researchers, students, alumni, investors, entrepreneurs and corporates in the development of new infrastructures, programs and tools for feeding the innovative ecosystem. This is the case of Stanford University, UC Berkeley and UCSF.

During the period under analysis (2007-2018) we have seen universities expanding their portfolio, taking new roles to embrace their entrepreneurs (i.e. business incubators and accelerators), strengthen the links with the business sector (to increase the commercialization of science) and keep the links between the startups and their VC funds. While there are many variants, having taken note of the different activities undertaken by universities to support entrepreneur-led startups, we classify them into four main areas. Below we elaborate on each of them, showing how universities in Silicon Valley are nurturing the innovation ecosystem.

\subsection{Entrepreneurial Education}

Interest in entrepreneurship education has experienced a significant growth, especially in business and management related disciplines, universities in Silicon Valley are extending such practices in other areas of knowledge as entrepreneurship is, by nature, interdisciplinary (Oosterbeek et al. 2010). For instance, the Lester Center for Entrepreneurship at UC Berkeley provides education on innovation and entrepreneurship for international students, professionals and researchers from different disciplines. Another example is Startup@Berkeley Law, a join initiative between the Law and Business \& Economy Schools. This program helps law students interested in the application of legal matters on startups and offers legal education and services for on-campus entrepreneurs.

The engineer led firm, rather than finance or marketing leadership, has been the sine qua non of Silicon Valley. This is strong evidence that it is possible to make the step from engineering to entrepreneur. Notwithstanding, nurturing engineers to think like entrepreneurs is another story. Engineers who have invented new technologies or are adept at creating solutions believe this to be the hard part, while bringing these solutions to the marketplace is just around the corner. Data however, reveals that reasons why businesses fail extend far beyond the technology. Said differently, the business step embodies far more risk than the invention itself. Exploring the business side of engineering and technology and learning what it takes to create or run a profitable business is 
increasingly gaining importance (Byers et al. 2013). But the case of engineering is not an isolated one. Similar arguments could be used in other disciplines such as medicine, law, journalism, etc.

Universities are increasingly providing additional events outside their main course in order to promote the acquisition of entrepreneurial skills. From the cases reviewed we highlight the Stanford Technology Venture Program (sTPV), consisting in teaching entrepreneurship to students of the Engineering School by providing them the knowledge, skills and attitudes to bring "bold ideas to life". Other related initiatives might take the form of business plan/lean competitions (e.g. Big Ideas@Berkeley), awards (e.g. QB3 Awards at UCSF), crossfaculty programs or clubs (e.g. spark at Stanford), among others.

\subsection{Sources of Knowledge}

In the context of this study, human capital can be understood as knowledge accumulation, that is, the knowledge stock—or technology—available at the university arising from any activity carried out. In this setting, two main strategies are envisioned for exploiting the knowledge accumulated: directly, by sell of products and services to the marketplace (via spin-offs) or indirectly, by cooperating with companies. This view assumes that universities give birth to the dual academic career. Beyond a student or a scientist, there is an entrepreneur, able to interface research and innovation. Accordingly, universities are sources of entrepreneurs. Therefore, it is not surprising to find VCs and corporate investors looking for new and appealing startups. This is especially the case in recent years of corporations that have created venture capital arms like Intel Capital, Google Ventures or Samsung NEXT Ventures.

Promoting the commercialization of knowledge through interactions with existing firms - the latter strategy—is another dimension explored by universities in Silicon Valley. The underlying rationale behind this strategy is to move research closer to private companies, increasing relationships with the private sector. This second path can materialize in multiple forms (e.g. cooperation agreements licensing of new technology, R\&D agreements). Universities, especially their researchers, are key partners for investors, who wish to understand new disruptions and if they are technological feasible and viable. Likewise, universities cannot only be seen as knowledge generators, but also with a valuable know-how, helping companies to identify new technologies, guiding in pre-competitive phases of development, and giving access to the talent, education and a wide array of resources.

Some examples of how universities are approaching this reality are the $I n$ novation Farm Teams (iFarm) at Stanford promoted by the OTL of Stanford in 2011 and the IPIRA launched in 2004 in UC Berkeley to increase the amount of 
applied research (in alliance with the industry). In the same direction, in 2003 the National Science Foundation (NSF) launched the i-Corps initiative to increase the impact of $n s f$ funded research. Another example is the Bay Area Node (UC Berkeley, UCSF and Stanford) that helps tech entrepreneurial teams with a new research application or innovative business model, to discover, validate and scale their business model using the Lean LaunchPad methodology.

There is still another trend, namely, that of looking for cross-campus collaborations or mingling departments. The creation of a new company typically requires people with different profiles and skills. An entrepreneurial team should include people from different backgrounds, as each of them might bring different knowledge and expertise. Universities are thus creating multidisciplinary programs where students from different disciplines work together in a project. This initiative help entrepreneurs meet peers and gain insight into how to work with them. This is the case of Stanford Predictive and Diagnostics Accelerator (spada) which helps - mainly in the field of healthinterdisciplinary teams to innovate in disease prediction and/or diagnosis.

\subsection{Investment Activity}

Universities are getting closer to investors (business angels, VC funds and corporate investors by linking them to potential campus entrepreneurs. Thus, going a step further than entrepreneurial education, universities in Silicon Valley have created networks of investors and introduced them to new student or researcher ventures. The main objective is to aid new entrepreneurs with seed money while providing the university an opportunity to bring in returns if the startup succeeds (Christini 2012). ${ }^{3}$

In the recent years there has been a proliferation of different types of funds, disrupting the market for VC funds. These include: university-backed VC funds, university-affiliated VC funds, student venture funds and VC funds with student programs. Increasingly, universities have created university-backed VC funds, offering a direct investment to entrepreneurs whose technologies have been created at or in partnership with a university. For instance, there is a $\$ 250 \mathrm{M}$ fund launched by the University of California in 2016. This fund is a clear example that universities are now investing in their own students or researchers' ventures, and demand shares in the early rounds. The Berkeley Ventures Fund from UC Berkeley belongs to this category. Analogously, in UCSF there is the Mission Bay Capital with two funds, the first created in 2009 with \$11.3 million in capital, and the second in 2015 with \$25 million. Another example is Stanford-StartX Fund co-founded by StartX, Stanford University, and Stanford Health Care, investing over \$120 million in more than 235 StartX companies. 
Student venture funds provide economic support to student entrepreneurs, but also assist with training and mentorship. They typically invest in student entrepreneurs and, in return, take a small share of the profits. These organizations can be created by just students or by students and faculty. Students manage, administer and make investment decisions on behalf of these funds. Investors might also take part as supervisors or advisors. By 2016, it has become one of the most prolific types of investment related to students or universities. One example is the Bay Area Dorm Room Fund, launched in 2012 and supported by national firm First Round Capital. It offers investments of $\$ 20$,ooo to new ventures. In order to reduce risk, First Run Capital does not obligate failed firms to pay back investments; as an alternative, if the entrepreneurs of the failed startup later create a successful startup, debt held by the fund will be converted to equity in the new firm. Another example is The House Fund, created in 2016 and run by UC Berkeley alumni. It is a $\$ 6 \mathrm{M}$ seed-stage fund, backed by Sherpa Capital, among others, focused on companies with student founders. They invest angel-sized checks, and syndicate the rest of the deal.

Lastly, larger VC firms, realizing the value of engaging with students, have created student ambassador programs. These programs are run year-by-year until the campus ambassador at a school graduates, who is then replaced with a new ambassador on each campus. These programs allow them to stay connected to new ideas on campus and bring in interesting companies. For example, Sequoia Capital, helped raise $\$ 2$ million for use by $Y$ Combinator, a seed funder, with high visibility making small $\$ 20$,ooo bets on startups such as Dropbox and Scribd, both of which were created by university students (Steiner 2015). By 2011, Xfund, a collaboration between New Enterprise Associates, Accel Partners and Breyer Capital, launched a $\$ 100$ million fund and set up two offices, one on Brattle Street in Cambridge, Massachusetts (home to MIT and Harvard) and the other in Menlo Park, California, adjacent to Stanford's campus. Sequoia went even further, bringing on Campus Ambassadors Program at 8 to 10 campuses across USA. These tech and entrepreneurially focused students let Sequoia know when interesting startups take root on campus, and they also make recommendations on the kinds of activities Sequoia should participate in to build a name at the school.

\subsection{Facilities: Incubators and Accelerator Programs}

To cope with the challenge to better interact with the business sector and commercialize research results, universities have formalized new policies as well as new infrastructures, including the creation or upgrade of regulatory frameworks for the IP, the establishment of offices of technology license (OTLS), as well as the creation of business incubators and accelerators. 
Prior to 2007, OTLs hardly considered either the university spin-off, nor the research transferred to a new venture as key indicators. Today, Silicon Valley's universities include both as metrics of activity inside the university's reports. Moreover, special programs to create new firms using отL technology have been created in recent years, providing the necessary infrastructure to begin a venture. UC Berkeley's SkyDeck created in 2011 is a 10,ooosq ft startup accelerator located in downtown Berkeley. Selected startups are offered facilities, mentoring and \$2,000 in capital for half a year (renewable for another half year), with the objective to attract investors in order to accelerate the way to the market. Resident teams have attracted over $\$ 93 \mathrm{M}$ in funding and have created near 650 jobs. Seven entrepreneurs from SkyDeck appear on a Forbes "3o under 30" list. Since its founding, it has supported 7o startup teams. In Mission Bay, UCSF provides $Q B 3953$ opened close to the campus. It is a full service 24,0oosq $\mathrm{ft}$ life science incubator offering offices for more than $5^{0}$ startups. Recently it has changed the name to $\mathrm{M} \mathrm{BC}$ Biolabs.

Lastly, there is another recent trend consisting in law firms partnering with university-related incubators or accelerators to give free orientation to new ventures, either directly or through the Faculties of Law and their students. For instance, Startup Legal Garage is a cross-campus experience at the Hastings College of the Law (UCSF) that gives free IP and legal services to new ventures, focus on local incubators. Another example is the Berkeley IP Lab within the Law School. This lab helps biotechnology startups manage intellectual property issues. Law students are working with biotech companies in a practice project led by the law firm Wilson Sonsini Goodrich \& Rosati.

Industry and Government Interaction with the Universities in the Ecosystem

The trends described in the previous section have taken place in relation with the other agents of the Triple Helix. A co-evolution process occurs through a conscious intervention of all the agents in an ecosystem of innovation (Nelson 1994). From a closer examination, we can elaborate on the drivers behind these trends (second research question), distinguishing between external and internal forces. External forces can materialize in two ways: interventions from the government or movements instigated by the industry. Some examples from the first group include the $i$-Corps program (federal government), the $Q B 3$ infrastructures (state of California) or the Mission Bay program to transform parts of the city. In all three cases universities and the industry ended up taking an active role in different ways and at different stages. These examples 
demonstrate that innovation in one of the spheres of the Triple Helix clearly impacts on the others.

Industry has pushed both universities and government to move a step forward. One example can be found in the rise of accelerator programs. Leading accelerator programs include funding and combine training with an access to powerful networks. Universities have not taken a step back and, either alone or in partnership with firms, are including a similar offer in their portfolio (e.g. Stanford-StartX Fund, Berkeley Ventures Fund, Mission Bay Capital at UCSF, The House Fund at UC Berkeley, Bay Area Dorm Room Fund).

As for the internal forces, the universities respond to the complex and uncertain conditions of the environment in which they operate with a wide range of initiatives and at different levels, such as UC Berkeley's Lester Center for Innovation and Entrepreneurship, and Stanford's Technology Venture Program. The latter initiative emerged as the Engineering School's response to the need of creating interdisciplinary programs that inspire entrepreneurial careers, disrupting the traditional way of teaching entrepreneurship (e.g. through business plan courses) during an earlier era when the Business School neglected the topic. As entrepreneurial organizations, the universities under analysis respond to challenges like the severe reduction in state of California support for Berkeley and opportunities of seeking funds from successful alumni and alumni firms.

At the instance of the Silicon Valley entrepreneurial community, the Stanford Business School has developed its own panoply of offerings. Other examples can be found in innovative ways to stimulate the creation of new start-ups among students and alumni through business plan/lean competitions (e.g. Big Ideas at UC Berkeley), awards (e.g. QB3 Awards at UCSF), or acceleration programs (e.g. UC Berkeley's SkyDeck, QB3 953 at UCSF). Perhaps the most significant development, with international effect, is the development of the $D$ School at Stanford, stemming from a half century ago collaboration between a mechanical engineering and an art professor.

The result (of both internal and external forces) is a dynamic ecosystem, as the movement of one of the agents also entails the movement of the other ones. In the case of Silicon Valley, all agents seem to evolve jointly and the ecosystem is growing organically, which in turn, signal its capacity to keep expanding in sustainable manner. Nevertheless, the "paradox of success" is a severely unbalanced Triple Helix, with a largely laisssez faire oriented industry helix, failing to make up for deficits in the other helices, especially government, but also universities, beyond the leading three (Scott and Kirst 2017). Although this study provides useful insights into the contribution of the universities in the Silicon Valley's ecosystem of innovation, we identified some future research lines as the role of Government and Corporates in the evolution of 
Silicon Valley and the impact of the university internationalization on Bay Area immigration culture.

Inability to address housing shortages especially threaten the viability of the region, with leading companies only recently beginning to wake up to the challenge. Viewed as a suburban area, some consider the peninsular to have been "built out" implying a need to slow down or locate future development in Austin, and elsewhere. The obvious alternative: "to go up" is typically negatively characterized as "Manhattanization" a fate worse than death! Nevertheless, as shopping centers that superseded the apricot orchards of the Valley's agricultural area are themselves increasingly made superfluous, tight urban foci located adjacent to public transportation, the next stage of Los Angelization in southern California is also indicated for its northern counterpart.

\section{Conclusion: Silicon Valley—a Metaphor in search of a Structure?}

Silicon Valley is a metaphor for a region that lacks a viable governmental structure. It is at the stage of New York, before its 1898 consolidation into a unified city. With the notable exception of the ecology of the Bay, a downside has emerged, a public-private imbalance revealing gaps in housing and transportation (Etzkowitz and Steiber 2019). Spread across multitudinous counties, towns and cities, Silicon Valley lacks sufficient governance capabilities to address the negative consequences of its overweening success.

An additional imbalance in academic capacities is, in part, a consequence of a more than half century old master plan strictly segmenting the public academic sphere that has limited individual institutional advancement. This gap has been partly redressed by establishment of branch campuses by universities in other parts of the country, like Carnegie Mellon and the Wharton School that ironically treat the region as an under-developed area, at least in its academic capabilities. Moreover, state government funding for public universities has declined drastically, from providing $40 \%$ of Berkeley's budget in the 1980 's to $14 \%$ percent at present. This gap is being redressed by a massive fund-raising campaign that expects to raise 6 billion dollars and increase the universities tenure track positions in coming years.

Re-balancing the Triple Helix will also require increased interaction among the spheres, a phenomenon that has declined in recent decades, placing the long-term innovation and carrying-capacity of the region at risk (Etzkowitz 2013). The innovative and sustainable economic development of Silicon Valley not only depends on the presence of strong universities, but on how they interact and overlap roles with the other agents of the Triple Helix model, looking for mutually strategic objectives and identifying cross-cutting issues which 
none of them can adequately deal individually (Kimatu 2016). Interactions between university, industry and government in a highly dynamic and volatile environment, represent a unique opportunity to recover from economic downturn, create new jobs, and promote a prolific, inclusive and economically sustainable development of regions in the long run.

In this work we have studied the evolution of the relationship of key universities in Silicon Valley to an archetype innovation ecosystem. We have especially focused on the role played by these universities during the past decade. The three universities (UC Berkeley, UCSF and Stanford) currently exemplify entrepreneurial university described by Etzkowitz (1983) and Clark (1998), encouraging networking and promoting the cross connection between disciplines and schools, offering opportunities for developing pilots and empowering students to become involved in research and prototype their ideas. However, they have taken distinctly different paths to arrive at this result. Stanford developed in close connection to the emerging technical industry in the region whereas Berkeley was more closely linked to government, making a swift transition to the Stanford Model in recent years in response to the decline of state government support. Berkeley is rapidly expanding upon the Stanford model with the greater human resources at its disposal and fewer inhibitions as a second mover rather than a path breaker. UCSF evolved in accordance with general university policy on technology transfer and the emergence of the local biotechnology industry to which it developed close links.

By combining quantitative with qualitative data, we have been able to respond to the research questions posed in the introduction. Concerning the first one (how have universities in Silicon Valley developed responses to the changes occurred in this entrepreneurial ecosystem over the years?) we have been able to identify four trends in which universities seem to have directed their efforts. As the knowledge-based society is more stringent on the role played by universities, these institutions have not remained static, but rather, evolved, adapting their way of operating to the new demands. More concretely they are: (1) fostering entrepreneurship education through the creation of new programs, competitions and activities, even in non-entrepreneurial courses and in multi-disciplinary contexts; (2) changing the focus of oTLs, including the commercialization of science and technology through entrepreneurs; (3) connecting universities and their communities (staff, students and alumni) with investors; and (4) creating advanced infrastructures for translational research, that may be expected to become ever more closely linked to incubation and accelerator programs, irrigating the "Valley of Death" between the identification and commercialization of useful findings.

Despite following a rigorous methodology, this study has some limitations, opening up new avenues for future research. First, although using quantitative 
data, information is mainly presented in a descriptive fashion. The figures and numbers shown allow us describing the evolution in quantitative terms; yet, a robust empirical analysis was constrained, mainly due to the lack of a consensus on how to map the evolution of an ecosystem of innovation. Also, data availability is an issue and not all universities collect data in the same way. On a related topic, figures about technology transfer outcomes may be skewed by a few very large successful businesses. While this is not an issue for the purpose of this work - we are interested on the quality and impact rather than on the quantity of the initiatives - this is an issue that should be highlighted. Second, several interviews were conducted and information gathered was triangulated with that obtained from other sources. Third, this study focuses on a very wellknown and successful ecosystem of innovation. We encourage future studies to extend the geographical scope and conduct additional research in other locations. Also, another promising area of study is that of cases of failure.

Taken as a whole, we believe this study to shed new light on how the movements of one of the agents in the Triple Helix model are affecting the behaviour of the others. As for the specific analysis of the role played by universities we have been able to characterise four practices-entrepreneurial education, sources of knowledge, investment activities and facilities - which are expected to inspire other universities willing to make an impact in their area of influence. The ultimate goal is to contribute to the existing discussion on how universities can help improve regional engagement. We expect that that the lessons learned from the universities in Silicon Valley will provide valuable insights and strategies for other universities in emerging and developing innovative ecosystems.

\section{Acknowledgments}

The authors would like to thank Monica Botey for her help with the interviews and collecting data. Likewise, the authors are really grateful to all interviewees that generously accepted to participate in this study.

\section{Endnote}

1 https://www.startupblink.com/blog/ecosystem-reports/.

2 https://www.globalinnovationindex.org/about-gii\#keyfindings.

3 It is rather difficult to calculate the number of universities in the usa that have VC funds, but it is clear that their popularity and diversity has increased during the last 10 years. 


\section{References}

Angel, D. P. (1991). High-Technology Agglomeration and the Labor Market: The Case of Silicon Valley. Environment and Planning A, 23, pp. 1501-1516.

Asheim, B. T., and Coenen, L. (2005). Knowledge Bases and Regional Innovation Systems: Comparing Nordic Clusters. Research Policy, 34, pp. 1173-119o.

Brundenius, C., Göransson, B., and Mello, J. M. C. (2016). Universities, Inclusive Development and Social Innovation: An International Perspective. Cham, Switzerland: Springer.

Byers, T., Seeling, T., Sheppard, S., and Weilerstein, P. (2013). Entrepreneurship: Its Role in Engineering Education. The Bridge, 43, pp. 35-40.

Cai, Y., and Liu, C. (2014). The Roles of Universities in Fostering Knowledge-Intensive Clusters in Chinese Regional Innovation Systems. Science and Public Policy, 42, pp. $15^{-29}$.

Carayannis, E. G., and Campbell, D. F. (2009). 'Mode 3' and 'Quadruple Helix': Toward a 21st Century Fractal Innovation Ecosystem. International Journal of Technology Management 46, pp. 201-234.

Carlaw, K., Oxley, L., Walker, P., Thorns, D. and Nuth, M. (2006). Beyond the Hype: Intellectual Property and the Knowledge Society/Knowledge Economy. Journal of Economics Survey, 20, pp. 633-69o.

CBInsights. (2012). The University Entrepreneurship Report. October 29. Available at: https://www.cbinsights.com/research/university-entrepreneurship-report/ (accessed 10 August 2019).

Charles, D. (2006). Universities as Key Knowledge Infrastructures in Regional Innovation Systems. Innovation-Abingdon, 19, pp. 117-130.

Christini, A. (2012). Why Universities Should Step up in Venture Investing. Nature Biotechnology, 30, pp. 933-936.

Clark, B. R. (1998). Creating Entrepreneurial Universities: Organizational Pathways of Transformation. Issues in Higher Education. New York: Elsevier Science.

Cooke, P., Roper, S., and Wylie, P. (2003). The Golden Thread of Innovation and Northern Ireland's Evolving Regional Innovation System. Regional Studies, 37, pp. 365-379.

Engel, J. S. (2015). Global Clusters of Innovation: Lessons from Silicon Valley. California Management Review, 57, pp. 36-65.

Engel, J. S. (2014). Global Clusters of Innovation: Entrepreneurial Engines of Economic Growth Around the World. Cheltenham, UK: Edward Elgar Publishing.

Engel, J. S., Berbegal-Mirabent, J., and Pique, J. M. (2018). The Renaissance of the City as a Cluster of Innovation. Cogent Business and Management, 5 (1), pp. 1-20. 
Engel, J.S., and Forster, F. (2014). USA: Silicon Valley, the Archetypal Cluster of Innovation. In: Engel, J. S., ed., Global Clusters of Innovation: Entrepreneurial Engines of Economic Growth around the World. Massachusetts: Edward Elgar, pp. 41-92.

Etzkowitz, H. (2019). Is Silicon Valley a Global Model or Unique Anomaly? Industryand Higher Education, 33 (2), pp. 83-95.

Etzkowitz, H. (2013). StartX and the "Paradox of Success": Filling the Gap in Stanford's Entrepreneurial Culture. Social Science Information, $5^{2}$ (4), pp. 6o5-627.

Etzkowitz, H. (1993). Technology Transfer: The Second Academic Revolution. Technology Access Report, 6 (7).

Etzkowitz, H. (1983). Entrepreneurial Scientists and Entrepreneurial Universities in American Academic Science. Minerva, 21, pp. 198-233.

Etzkowitz, H., Germain-Alamartine, E., Keel, J., Kumar, C., Smith, K. N., and Albats, E. (2019). Entrepreneurial University Dynamics: Structured Ambivalence, Relative Deprivation and Institution-Formation in the Stanford Innovation System. Technological Forecasting and Social Change, 141 (C), pp. 159-171.

Etzkowitz, H., Mack, A., Schaffer, T., Scopa, J., Guo, L., and Pospelova, T. (2018). Innovation by Design: SPARK and the Overcoming of Stanford University's Translational "Valley of Death" in Bio-Medicine. Managerial and Decision Economics. doi. org/10.1002/mde.2966.

Etzkowitz, H., and Steiber, A. (2019). Silicon Valley: Too Much Success? In: Nourani, C. F., ed., Computing Predictive Analytics, Business Intelligence, and Economics: Modeling Techniques with Start-ups and Incubators. Oakville, Canada: Apple Academic Press Inc., pp. 155-170.

Etzkowitz, H., and Zhou, C. (2018a). Innovation Incommensurability and the Science Park. R\&D Management, 48 (1), pp. 73-87.

Etzkowitz, H., and Zhou, C. (2018b). The Triple Helix: University-Industry-Government Innovation and Entrepreneurship. London: Routledge.

Florida, R. (2012). San Francisco's Urban Tech Boom. SFgate, September 8. Available at: http://www.sfgate.com/opinion/article/San-Francisco-s-urban-techboom-3850039.php (accessed 3 March 2016).

Gold, B. (2018). Silicon Valley Success Factors - The Concept of Intra-Nationalization. In: Gold, B., ed., Silicon Valley Start-ups and Corporate Innovation. Wiesbaden: Springer Gabler, pp. 79-128.

Goddard, J., Hazelkorn, E., Kempton, L., and Vallance, P. (2016). The Civic University. The Policy and Leadership Challenges. Cheltenham: Edward Elgar.

Guerrero, M., Cunningham, J., and Urbano, D. (2015). Economic Impact of Entrepreneurial Universities' Activities: An Exploratory Study of the United Kingdom. Research Policy, 44, pp. 748-764. 
Harris, R. G. (2011). The Knowledge-Based Economy: Intellectual Origins and New Economic Perspectives. International Journal of Management Reviews, 3, pp. 21-40.

Hazelkorn, E. (2005). University Research Management: Developing Research in New Institutions. Paris: OECD.

Henton, D., and Held, K. (2013). The Dynamics of Silicon Valley: Creative Destruction and the Evolution of the Innovation Habitat. Social Science Information, 52 (4), pp. 539-557.

Kenney, M., and Florida, R. (2000). Venture Capital in Silicon Valley: Fueling New Firm Formation. In: Kenney, M., ed., Understanding Silicon Valley: The Anatomy of an Entrepreneurial Region, Stanford: Stanford University Press, pp. 98-123.

Kimatu, J. N. (2016). Evolution of Strategic Interactions from the Triple to Quad Helix Innovation Models for Sustainable Development in the Era of Globalization. Journal of Innovation and Entrepreneurship, 5, pp. 1-7.

Leydesdorff, L., and Etzkowitz, H. (1996). Emergence of a Triple Helix of UniversityIndustry-Government Relations. Science and Public Policy, 23, pp. 279-286.

Liu, C., and Cai, Y. (2017). Triple Helix Model and Institutional Logics in Shenzhen Special Economic Zone. Science and Public Policy, 45, pp. 221-231.

Merton, R. K., Fiske, M., and Kendall, P. L. (1990). The Focused Interview: A Manual of Problems and Procedures. New York: Free Press.

Morgan, K. (2004). The Exaggerated Death of Geography: Learning, Proximity and Territorial Innovation Systems. Journal of Economic Geography, 4, pp. 3-21.

Mowery, D. C., Nelson, R. R., Sampat, B. N., and Ziedonis, A. A. (2001). The Growth of Patenting and Licensing by US Universities: An Assessment of the Effects of the Bayh-Dole Act of 1980. Research Policy, 30, pp. 99-119.

Nelles, J., and Vorley, T. (2010). From Policy to Practice: Engaging and Embedding the Third Mission in Contemporary Universities. International Journal of Sociology and Social Policy, 30, pp. 341-353.

Nelson, R. R. (1994). The Co-Evolution of Technology, Industrial Structure, and Supporting Institutions. Industrial and Corporate Change, 3, pp. 47-63.

Nilsson, J. E. (2005). The Role of Universities in Regional Innovation Systems: A Nordic Perspective. Copenhagen: Copenhagen Business School Press.

Oh, D. S., Phillips, F., Park, S., and Lee, E. (2016). Innovation Ecosystems: A Critical Examination. Technovation, 54, pp. 1-6.

Oosterbeek, H., van Praag, M., and Ijsselstein A. (2010). A. The Impact of Entrepreneurship Education on Entrepreneurship Skills and Motivation. European Economic Review, 54, pp. 442-454.

Orecchini, F., Valitutti, V., and Vitali, G. (2012). Industry and Academia for a Transition Towards Sustainability: Advancing Sustainability Science through UniversityBusiness Collaborations. Sustainability Science, 7, pp. 57-73. 
Pique, J. M., Berbegal-Mirabent, J., and Etzkowitz, H. (2018). Triple Helix and the Evolution of Ecosystems of Innovation: The Case of Silicon Valley. Triple Helix, 5, pp. 1-21.

Pique, J. M., Miralles, F., Teixeira, C. S., Gaspar, J. V., and Filho, J. R. B. R. (2019). Application of the Triple Helix Model in the Revitalisation of Cities: The Case of Brazil. International Journal of Knowledge-Based Development, 10, pp. 43-74.

Rothaermel, F. T., Agung, S. D., and Jiang, L. (2007). University Entrepreneurship: A Taxonomy of the Literature. Industrial and Corporate Change, 16, pp. 691-791.

Saxenian, A. (1996). Regional Edvantage. Cambridge, MA: Harvard University Press.

Saxenian, A. (2006) The New Argonauts: Regional Advantage in a Global Economy. Cambridge, MA: Harvard University Press.

Scott, R., and Kirst, M. (2017). Higher Education and Silicon Valley: Connected but Conflicted. Baltimore: Johns Hopkins University Press.

Shattock, M. (2009). Entrepreneurialism in Universities and the Knowledge Economy. Maidenhead: Society for Research into Higher Education and Open University Press.

St. Clair, D. J. (1998). The Gold Rush and the Beginnings of California Industry. California History, 77, pp. 185-208.

Stanford University (2019). Office of Technology Licensing. Annual Reports. Available at: https://otl.stanford.edu/about/about-us/annual-reports (accessed 24 October 2019).

Steiner, C. (2015). Big Investors on Campus: Why VCs are Scouting Student Startups. Innovation and Intellectual Property. September 15. Available at https://www .reuters.com/article/idUSL1N11K1W72O15O915 (accessed 15 May 2019).

Tuunainen, J. (2005). Hybrid Practices? Contributions to the Debate on the Mutation of Science and University. Higher Education, 5o, pp. 275-298.

UC Berkeley (2019). Innovation and Entrepreneurship Highlights (2014-2015). Available at: https://vcresearch.berkeley.edu/excellence/innovation-and-entrepreneurship (accessed 1 September 2019).

UC Berkeley (2014). Stimulating Entrepreneurship in the Bay Area and Nationwide: An Exploration of the Economic Contributions of UC Berkeley through Company Formations by Alumni, Faculty and Affiliates. Available at: https://www.ucop.edu/ innovation-alliances-services/_files/Econ\%2oImpact\%2oRpts/UCB-StimulatingEntrep-rpt-2014.pdf (accessed 15 May 2019).

University of California (2019). Technology Commercialization Reports (2007-2016). Available at: https://www.ucop.edu/innovation-alliances-services/innovation/ innovation-impact/technology-commercialization-report.html (accessed 15 May 2019).

Uyarra, E. (2010). Conceptualizing the Regional Roles of Universities, Implications and Contradictions. European Planning Studies, 18, pp. 1227-1246. 


\section{Appendix}

\section{Appendix A}

In this appendix we provide a list and a short description of some of the most relevant entrepreneurial activities (Table A.1), incubators and accelerators (Table A.2), as well as funding opportunities (Table A.3) available at UC Berkeley for the period (20072016). Descriptions provided here have been extracted from the different websites and summarized.

TABLE A.1 Entrepreneurial education and support activities at UC Berkeley

Lester Center for The Lester Center is internationally recognized for providing Innovation and leading edge entrepreneurship education and scholarly research Entrepreneurship in innovation at the hub of the UC Berkeley and the San Francisco Bay Area's multidisciplinary startup community. The offerings include Steve Blank's Lean LaunchPad class and the National Science Foundation's Innovation Corps. They are an integral part of the innovation ecosystem at UC Berkeley. The offices are located in the Faculty Building of the Haas School of Business at the University of California, Berkeley.

LAUNCH It is the startup accelerator competition from the Haas School (1999) of Business. Over the years it has evolve through different formats - from business plans to model canvas and pitch deck - until the current accelerator model (2015) designed to guide companies with validated products to fundable businesses. The Global Social Venture Competition and the Venture Capital Investment Competition are also initiatives of the Berkeley-Hass Entrepreneurship Program both launched before 2006.

Pantas and Ting Launched at the College of Engineering, this center is focused on Sutardja Center for the study and practice of "technology-centric" entrepreneurship and innovation. Since its first course in 2005, some initiatives Entrepreneurship have been added: the Challenge Lab Course, an industry-focused \& Technology (2005) course that creates a space for undergraduate students to form teams and develop ideas; the Collider Projects, a research-centric program open to all Berkeley researchers and students through which successful teams win cash prizes to help develop their ideas and participate in campus incubators; the Venture Lab (2008), an incubator that helps Berkeley participants to launch startup companies in a real world setting through faculty-led 
Big Ideas@

Berkeley

(2006)

New Business

Practicum

(2007)

Cleantech to

Market

(2009) guidance in business model development and identification of early-stage financing; and the Delta Prize, which provides a two and a half month mentoring program that culminates in the awarding of $\$ 15$,ooo annually to the top teams that show the most progress of their ideas.

Run by the Blum Center for Developing Economies. Business plan competition where interdisciplinary teams compete to receive up to $\$ 10$,000 in grant funding.

This practicum brings law and students from the Haas School of Business together in teams to advise entrepreneurs on the non-IP-related legal issues involved in starting a business. One-semester program at the Energy Institute at Haas Business School, that provides commercialization support for cleantech technology teams seeking to explore and develop market opportunities. The program includes training, technology assessment, market exploration, funding, licensing and a presentation of the findings.
B PEP

(2010)

Bay Area NSF

Innovation Corps

(2013)

Biomedical

Manufacturing

Network

(2013)

Bio-Manufacturing to Market (2013)

Berkeley IP Lab (2015)
The Berkeley Postdoctoral Entrepreneurship Program (В РЕР) provides entrepreneurship support and hosts professional development workshops.

The Hass Business School at UC Berkeley, UCSF and Stanford offers this curriculum-focused bootcamp program that engages participants in moving products out of the lab and into the market.

Grant from the US Departments of Commerce, Energy and Labor, the US Small Business Administration, and the National Institute of Standards and Technology. This initiative gives small biotech companies access to specialist advisers in intellectual property, fundraising, financial planning and projections, and federal grants.

Program that provides hands-on experiences in which UC Berkeley science and engineering undergraduates as well as students from the Laney Community College collaborate with startups, medium, and large-sized companies located in the East Bay.

Within the Law School, this lab helps biotechnology startups manage intellectual property issues. Law students are paired with biotechnology startups in a practice project led by the head of law firm Wilson Sonsini Goodrich \& Rosati's patents and innovation counseling practice. 
Jacobs Institute for

Design Innovation (2015)

Startup@Berkeley Law (2015)

IPIRA - Office of Intellectual Property \& Industry Research Alliances (2004)
This program from the Engineering School provides resources for projects that are at the intersection of technology and design

A join initiative between the Law and Business \& Economy Schools. The program supports law students with an interest in the legal issues surrounding entrepreneurship and provides legal education and services for the Berkeley startup community at large.

UC Berkeley's Office of Intellectual Property \& Industry Research Alliances (IPIRA) was created in 2004 to enhance the research enterprise of the Berkeley campus by establishing and maintaining multifaceted relationships between Berkeley researchers and private companies.

TABLE A.2 Incubators and accelerators at UC Berkeley

QB3 Garage

(2006)
$\mathrm{QB}_{3}$ Garage is an 8oosq $\mathrm{ft}$ facility located on campus. Space is limited to $3-4$ people for each team. Residents stay $2-3$ years.

QB3 East Bay Innovation $\mathrm{QB}_{3}$ is one of the four California Institutes for Science and Center Innovation founded by Governor Gray Davis. QB3 has (2010) facilitated major discoveries and innovation, in the life sciences. This facility offers 8 ,ooosq $\mathrm{ft}$ of lab and office space and includes access to shared research equipment.

SkyDeck (2011) A 10,0oosq ft startup accelerator located in downtown Berkeley. Selected startups receive office space, mentoring and $\$ 2,000$ in funding for six months (renewable for another six), with the goal of attracting private investment and achieving an accelerated path to market. Resident teams have attracted over $\$ 93 \mathrm{M}$ in investment and have produced an estimated $65^{\circ}$ jobs. Seven founders from SkyDeck appear on a Forbes " 30 under 30 " list. Since its founding, it has supported 70 startup teams.

Berkeley Startup Cluster Startups affiliated with the university find resources such (2012) as events, help in recruiting local employees, and assistance with finding commercial or co-working space near the campus. 
CITRIS Foundry (2013)
An applied tech incubator that provides residents with work space, equipment, computer time, mentoring and a small amount of financial support-typically $\$ 5,000$, in exchange for $2 \%$ equity pre-evaluation. Residents also have access to the Invention Lab, a rapid prototyping facility for hardware companies, and may be introduced to angel and venture investors. Since 2013, 23 companies have been incubated.

\section{TABLE A.3 Funding opportunities at UC Berkeley}

\begin{tabular}{|c|c|c|}
\hline \multirow[t]{2}{*}{$\begin{array}{l}\text { Fellow funding for } \\
\text { entrepreneurs }\end{array}$} & Bakar Fellows (2010) & $\begin{array}{l}\text { Provides support to early-career } \\
\text { faculty and students whose } \\
\text { research shows commercial } \\
\text { promise. Each year, five fellows are } \\
\text { selected by a committee to receive } \\
\text { translational research support for } \\
\text { both early stage startups and } \\
\text { technology licensing activities for } \\
\text { up to five years. }\end{array}$ \\
\hline & $\begin{array}{l}\text { Signatures Innovation } \\
\text { Fellows Program } \\
(2015)\end{array}$ & $\begin{array}{l}\text { Supports innovative research by } \\
\text { UC Berkeley faculty and research- } \\
\text { ers in the data science and } \\
\text { software fields with a special focus } \\
\text { on projects with commercial } \\
\text { potential. }\end{array}$ \\
\hline \multirow[t]{2}{*}{$\begin{array}{l}\text { Creative, indepen- } \\
\text { dently-run student } \\
\text { entrepreneur } \\
\text { programs }\end{array}$} & $\begin{array}{l}\text { Design Engineering } \\
\text { Collaborative } \\
(2012)\end{array}$ & $\begin{array}{l}\text { Provides student entrepreneurs } \\
\text { with a small on-campus workspace } \\
\text { (several hundred square feet) and } \\
\text { community support to develop and } \\
\text { prototype ideas. }\end{array}$ \\
\hline & $\begin{array}{l}\text { Free Ventures } \\
(2013)\end{array}$ & $\begin{array}{l}\text { A student-run accelerator that } \\
\text { provides mentors and several } \\
\text { thousand dollars in support. To } \\
\text { date, the program has supported } \\
25 \text { students who have raised more } \\
\text { than } \$ 25 \text { million in venture } \\
\text { funding in the last two years. }\end{array}$ \\
\hline
\end{tabular}




\begin{tabular}{|c|c|c|}
\hline & $\begin{array}{l}\text { Cal Hacks } \\
(2014)\end{array}$ & $\begin{array}{l}\text { A "build anything" } 48-72 \text { hour } \\
\text { hackathon. In its first year, Cal } \\
\text { Hacks had a } \$ 25 \text {, ooo budget, } \\
\text { raised by students from private } \\
\text { sponsors, with in-kind support } \\
\text { from CITRIs. An expanding area of } \\
\text { activity, student-led hackathons } \\
\text { were organized at nine UC } \\
\text { campuses in } 2015 \text { and are now } \\
\text { connected system-wide through } \\
\text { the UC Hack Alliance. }\end{array}$ \\
\hline & $\begin{array}{l}\text { Bay Area Dorm Room } \\
\text { Fund } \\
(2012)\end{array}$ & $\begin{array}{l}\text { It is a student-run venture fund } \\
\text { backed by First Round. The fund } \\
\text { invests in startups where at least } \\
\text { one person on the founding team } \\
\text { is a student. The investment team } \\
\text { is run by student leaders, entrepre- } \\
\text { neurs, and innovators. They have } \\
\text { invested in } 200 \text { startups that have } \\
\text { raised } \$ 400 M \text {. }\end{array}$ \\
\hline \multirow{3}{*}{$\begin{array}{l}\text { Initiatives led by UC } \\
\text { Berkeley alumni }\end{array}$} & Berkeley Founders & A private entity fund that each year \\
\hline & $\begin{array}{l}\text { Group } \\
(2014)\end{array}$ & $\begin{array}{l}\text { supports four Berkeley startups } \\
\text { with } \$ 25 \text {,ooo in pre-seed funding } \\
\text { each, six months of office space in } \\
\text { Foundation Capital's somA office } \\
\text { in San Francisco, mentorship, and } \\
\text { access to the Foundation Capital's } \\
\text { business networks. }\end{array}$ \\
\hline & The House Fund (2016) & $\begin{array}{l}\text { The fund has raised } \$ 6 \mathrm{M} \text { to } \\
\text { support pre-seed and seed-stage } \\
\text { companies with ties to the } \\
\text { university. It is backed by Sherpa } \\
\text { Capital, among others. }\end{array}$ \\
\hline
\end{tabular}




\section{Appendix B}

In this appendix we provide a list and a short description of some of the most relevant entrepreneurial activities (Table B.1), industry programs (Table B.2), and spaces, awards and funding opportunities (Table B.3) available at UCSF for the period (20072016). Descriptions provided here have been extracted from the different websites and summarized.

TABLE B.1 Entrepreneurial education and support activities at ucsf

Startup Legal Garage (2011)

Entrepreneurship Center (re-launched in 2012)

Lean LaunchPad (2014)

LaunchPad
A cross-campus experience at UC Hastings College of the Law, that provides pro bono corporate and intellectual property services to early-stage startups, drawn primarily from local incubators. This initiative has two primary components: classroom lectures, and field work supervised by practicing attorneys. It offers students the opportunity to practice their skills in legal topics such as contracts, entity formation, intellectual property, and regulatory issues in a real world setting. At the same time, it provides to participating startups free legal advice, and affords participating lawyers the opportunity to identify future clients.

The center receives limited university funding and temporary support from an I-Corps grant from the National Science Foundation. It supports entrepreneurially-driven students. The program provides them with the basic tools that are needed to move from an idea to the marketplace. Through coursework, mentors and advisers drawn from industry, students learn how to develop a business plan, create alliances, manage team dynamics, negotiate, and prepare for investment. Course offered through the Entrepreneurship Center that helps entrepreneurs determine whether an idea is viable in the commercial marketplace using a model originally created by Stanford and Berkeley Professor, Steve Blank.

An unrelated program under the UCSF's Clinical and Translational Science Institute, which showcases UCSF innovators through an online platform that tracks and supports successive stages of a product's development. 
TABLE B.2 Industry programs adjacent to ucsp's Mission Bay campus

Incubator space at FibroGen (2009)

CoLaborator

(Bayer incubator)

(2012)

Illumina Accelerator (2014)
QB3 partnered with biotech company Fibro-Gen, the San Francisco Chamber of Commerce and the San Francisco Center for Economic Development, the first off-campus incubator in Mission Bay. A 6,ooo sq foot life sciences incubator that provides lab space to emerging companies whose technologies are aligned with Bayer's mission. In addition to UCSF facilities, residents have access to Bayer's research network and its environmental health and safety licenses. UCSF's core facilities are a draw, particularly labs that startups can access for a fee. A six-month business acceleration program for genomic companies drawn from both academia and industry. It offers $\$ 100,000$ in financial support, plus $20 \%$ research assistant time and access to sophisticated medical instrumentation. Other services include pitch preparation, partner support, non-exclusive access to Illumina's intellectual property, and biweekly workshops on industry trends, business models, and scalable business methods.

TABLE B.3 Spaces, awards and funding opportunities at UCSF

\begin{tabular}{|c|c|c|}
\hline $\begin{array}{l}\text { Clinical and } \\
\text { Translational } \\
\text { Science Institute }\end{array}$ & $\begin{array}{l}\text { Catalyst Awards } \\
(2009)\end{array}$ & $\begin{array}{l}\text { A proof-of-concept competition with prizes } \\
\text { of up to } \$ 100, \text { ooo for medical inventions and } \\
\$ 30, \text { ooo for digital ones. The fund seeks for } \\
\text { research with potential for medical treat- } \\
\text { ments/technology. }\end{array}$ \\
\hline \multirow{3}{*}{$\begin{array}{l}\text { Governor Gray } \\
\text { Davis Institutes for } \\
\text { Science and } \\
\text { Innovation } \\
\text { (under } \mathrm{QB}_{3} \text { ) }\end{array}$} & Mission Bay & It has two funds, the first launched in 2009 \\
\hline & $\begin{array}{l}\text { Capital } \\
(2009)\end{array}$ & $\begin{array}{l}\text { with } \$ 11.3 \text { million in capital, and the second } \\
\text { in } 2015 \text { with } \$ 25 \text { million. }\end{array}$ \\
\hline & $\begin{array}{l}\text { QB3 } 953 \\
(2013)\end{array}$ & $\begin{array}{l}\text { Opened in Mission Bay close to UCSF's } \\
\text { campus, it is a full service } 24, \text { ooosq } \mathrm{ft} \text { life } \\
\text { science incubator providing space and equip- } \\
\text { ment for more than } 5 \text { o UC-affiliated }\end{array}$ \\
\hline
\end{tabular}




$\begin{array}{ll} & \begin{array}{l}\text { and other startups. Recently it has changed } \\ \text { the name to M } \mathrm{CC} \text { Biolabs. }\end{array} \\ \text { QB3 Awards } & \text { These awards recognize early-stage life } \\ \text { (2015) } & \text { sciences innovators and job creators in the } \\ & \text { San Francisco Bay Area. } \\ \text { QB3 Startup in } & \text { This program helps entrepreneurs to } \\ \text { a Box } & \text { incorporate, create a business structure and } \\ & \text { establish a commercial bank account, plus an } \\ & \text { SBIR funding workshop and, legal support in } \\ & \text { collaboration with the UC Hastings Startup } \\ & \text { Legal Garage. }\end{array}$

\section{Appendix C}

In this appendix we provide a list and a short description of some of the most relevant entrepreneurial activities (Table C.1), incubators and accelerators (Table C.2), as well as funding opportunities (Table C.3) available at Stanford University for the period (2007-2016). Descriptions provided here have been extracted from the different websites and summarized.

TABLE C.1 Entrepreneurial education and support activities at Stanford University

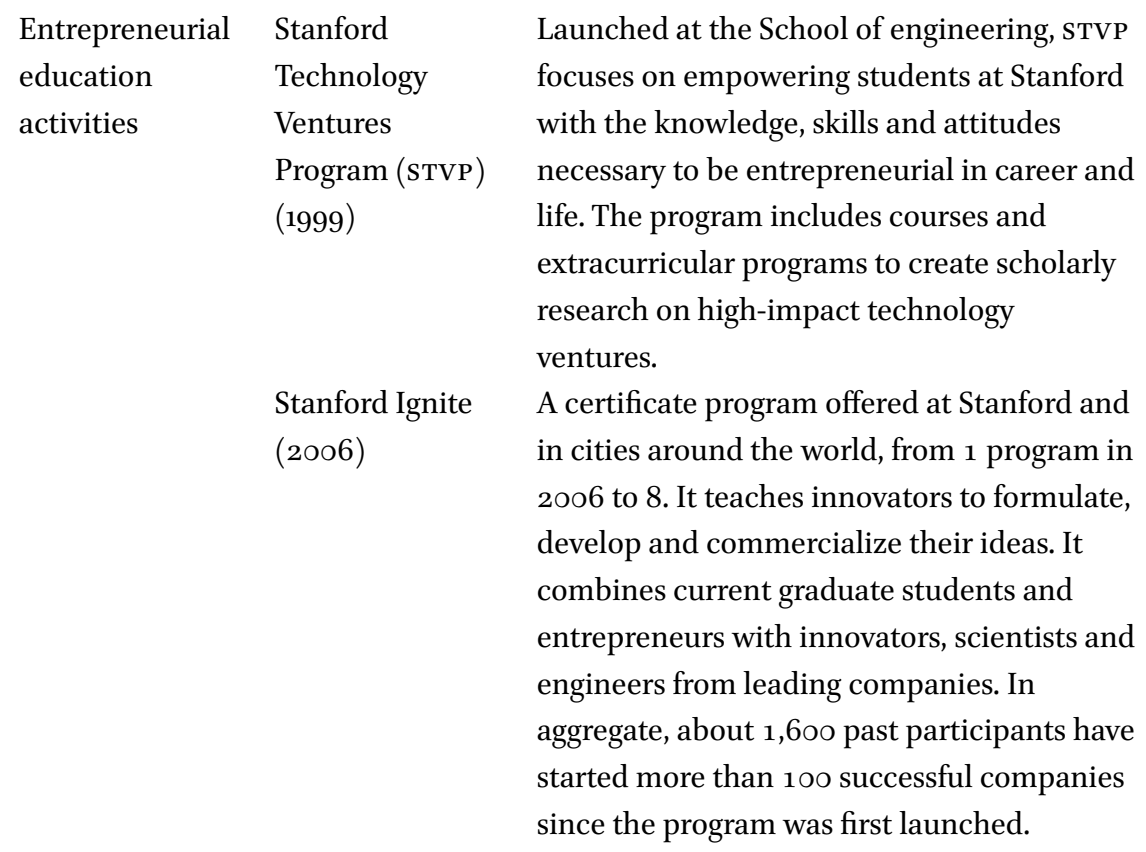


Stanford

Entrepreneurship

Network (SEN)

(2007)

Startup Garage

(2013)

Stanford Alumni

Mentoring

(2002)

BASES

(1996)
SEN is a federation of three dozen entrepre-

neurship-related campus organizations that

conduct research, teach courses and provide outreach services. Stanford-affiliated groups may join SEN by contacting its administrator through its website.

An intensive, hands-on, project-based course in which students design and test new business concepts that address real-world needs. Some companies that have been founded out of the Startup Garage course include DoorDash, Bipsync, DogHero, ClearMetal, MindRight, TalkingPoints and Boom Fantasy.

Students and alumni are matched by their interests to form a mentoring relationship involving in-depth discussions over a 6-month period. Mentors who are experienced entrepreneurs.

BASES seeks to foster and develop the business potential of Stanford students interested in entrepreneurship. It is the largest entrepreneurship organization at Stanford, completely student-run, volunteer driven, and privately funded.

Other programs Stanford's General It is the precursor to Spectrum. In May 2008 that support Clinical Research the center was awarded an NiH-funded стSA entrepreneurial Center (GCRC) (1962) grant and has made significant strides in transforming the clinical and translational research support infrastructure and scholarly environment at Stanford. Spectrum is an independent center within Stanford University that supports health-related research activities: provides funding for early-stage ideas and help researchers develop proof-ofconcept research and prototypes. These seed grants are awarded in the areas of medtech, therapeutics, diagnostics, population health sciences and community engagement. 


$\begin{array}{ll}\text { SPARK } & \begin{array}{l}\text { It is a partnership between the School of } \\ \text { (2006) }\end{array} \\ & \begin{array}{l}\text { Medicine and volunteers from biotech, } \\ \text { pharma, and healthcare investment to } \\ \text { advance new biomedical research discoveries } \\ \text { into promising new treatments for patients. } \\ \text { It provides funding, education, access to } \\ \text { facilities, expert advice, and mentorship. }\end{array} \\ \text { Association of } & \begin{array}{l}\text { Founded by three Stanford postdocs to } \\ \text { Industry-Minded }\end{array} \\ \text { address the growing needs of postdoctoral } \\ \text { sionals (AIMs) } \\ \text { (2010) }\end{array}$

TABLE C.2 Incubators and accelerators at Stanford University

StartX

(formerly ssE Labs)

(2009)
A student-run program aimed at finding additional ways to engage the alumni community with early-stage founders or students. StartX is the premier Stanford Student Startup Accelerator. Headquartered in Aol's Palo Alto offices, StartX, a division of Stanford Student Enterprises, provides a select group of founders and their companies with a community of other like-minded founders, custom real-time education, mentorship from 
TABLE C.2 Incubators and accelerators at Stanford University (cont.)

Stanford Predictive and

Diagnostics Accelerator (SPADA)

(2013)

Stanford Venture Studio @ the Graduate School of Business top Silicon Valley industry experts and entrepreneurs, free legal services, workshops, office space and more. StartX takes zero equity and welcomes founders with ideas from any industry. Today, it is a thriving nonprofit that has helped develop and grow over 450 companies. Part of Spectrum Program, SPADA assists interdisciplinary innovators in research, development and deployment of technologies that improve human health through disease prediction and/or diagnosis. The studio supports entrepreneur students through co-working space, workshops and training, one-to-one advising, online resource kit with recommendations for tools, guides, and service providers, active peer collaboration and support from students and alumni, social activities to foster community connections and close ties with clubs, organizations, and programs across campus, among others.

TABLE C.3 Funding opportunities at Stanford University

Stanford Byers Center for Biodesign (2000)

Stanford Angels \& Entrepreneurs (SA\&E) (2010)
In 15 years, the center has founded 41 companies through the program. As of 2016, these companies have helped more than 500,ooo patients and raised over \$28o million in funding. Founded by 2 Stanford alumni and venture capitalists, $S A \& E$ seeks to strengthen Stanford's entrepreneurial community by fostering relationships among potential investors and entrepreneurs. Beyond funding startups, SA\&E supports both angels and entrepreneurs through educational programs and give them access to the Stanford entrepreneurial ecosystem. To date, SA\&E has helped fund over 28 startups. 
Stanford-StartX Fund (SSF)

(2013)

TomKat Center's Innovation Transfer Program

(2013)
Co-founded by StartX, Stanford University, and Stanford Health Care, the SsF has invested over $\$ 120$ million in $235^{+}$ StartX companies. SSF is available only to StartX companies with a Stanfordaffiliated founder: it is opt-in and utilizes clear objective criteria for investment. In order for SSF to invest in a particular round, the round size must be $\$ 5$ ook or greater and 30\%+ must have come from professional investors. ss F will invest $10.0 \%$ of a round.

The Center for Sustainable Energy has an Innovation Transfer Program that helps Stanford inventors bridge the gap between research and commercialization. They award grants to develop prototypes, refine business plans, and conduct customer trials and market research. Teams working on funded projects are assigned an industry mentor for ongoing guidance in how best to externalize their innovation by assessing market opportunities, planning for commercialization, exploring strategic partnerships, or preparing to launch a startup. Since the program began it has funded dozens of projects and more than 12 spin-off companies. 